\title{
A feasibility study report on Contract Farming as part of Agro Promotion Scheme of Govt. of India A case study on Farmer based Indore
}

\author{
Dr. Deepa Joshi \\ Associate Professor, Shri Vaishnav Institute of Management.
}

\section{Introduction}

The agricultural produce sector has been one of the most important components of the Indian economy. The increasing trend of agricultural production has brought, in its wake, new challenges in terms of finding market for the marketed surplus. There is also a need to respond to the challenges and opportunities, that the global markets offer in the liberalized trade regime. To benefit the farming community from the new global market access opportunities, the internal agricultural marketing system in the country needs to be integrated and strengthened. Government of India is striving to prepare the Indian agricultural markets and marketing environment so as to provide maximum benefit to the producers and in turn, compete with the global markets. Agriculture and agricultural marketing need to be re-oriented to respond to the market needs and consumer preferences. Agricultural marketing reforms and creation of marketing infrastructure has been initiated to achieve the above purpose. It is well known that the small farmers in our country doo not have the economic strength to retain their farm produce with themselves for the "market prices" to become favorable.

Do not have direct access to the large buyers in the country and they have to sale their goods at the local market price basis through the brokers who in turn takes maximum profits by retaining the goods due to their financial strength. There is a felt need in the country to provide to the farming community with facilities for Scientific storage and good marketing infrastructures so that wastage and produce deterioration are avoided, on one hand and guide them to approach the potential big buyers through such types marketing infrastructures projects. An expert committee set up by the ministry of agriculture has estimated that an investment requirement of 11172 crores in nest 10 years would be necessary for infrastructure developments in agriculture marketing.

A godown along with the grading and standardization facility will enable small farmers to enhance their holding capacity in order to sell their produce at remunerative prices and avoid distress sales and also to retain seeds by standardization process through their own produce. Accordingly, in the direct marketing infrastructures scheme the capital investment subsidy scheme has been introduced.

\section{Objective of Study}

To study about the feasibility of contract farming scheme of ministry of agriculture with special reference to Indore District, as has been taken a live project as base.

The objectives of the scheme are:

\section{Objectives of The Scheme}

- To provide additional agricultural marketing infrastructure to cope up with the large expected marketable surpluses of agricultural and allied commodities including dairy, poultry, fishery, livestock and minor forest produce.

- To promote competitive alternative agricultural marketing infrastructure by inducement of private and cooperative sector investments that sustain incentives for quality and enhanced productivity thereby improving farmers' income.

- To strengthen existing agricultural marketing infrastructure to enhance efficiency.

- To promote direct marketing so as to increase market efficiency through reduction in intermediaries and handling channels thus enhancing farmers' income.

- To provide infrastructure facilities for grading, standardization and quality certification of agricultural produce so as to ensure price to the farmers commensurate with the quality of the produce.

- To promote grading, standardization and quality certification system for giving a major thrust for promotion of pledge financing and marketing credit, introduction of negotiable warehousing receipt system and promotion of forward and future markets so as to stabilize market system and increase farmers' income.

- To promote direct integration of processing units with producers.

- To create general awareness and provide education and training to farmers, entrepreneurs and market functionaries on agricultural marketing including grading, standardization and quality certification. 
- To promote Direct Marketing so as to increase market efficiency through reduction in Intermediaries and handling channels thus enhancing farmer's income

- To promote direct integration of processing units with processors

- To promote grading standardization and quality certification for giving a major thrust for

- $\quad$ Promotion of pledge financing and marking credit.

- To promote incorporation of provision allowing/ setting up registered contract farming program by the private entrepreneurs.

The proposed project is for setting up of Contract Farming to support farmers of near-by villages.

\section{Details about farmer}

Farmer's selection criteria

The farmer has to hold agriculture land, in his / her name. As per the scheme Govt. of India gives $33 \%$ subsidy to female farmers who have direct income from agriculture.

\section{Profile}

The farmer in this project has to set up the infrastructure required for Contract Farming. She has entered into the contract with M/S ABC Seeds and Biotech Ltd wherein the later will lease out the premises and other infrastructure of the business. The said business will be run by M/S ABC Seeds and Biotech Ltd whose name is synonymous with the leading private producer and marketer of quality soybean and wheat seeds in India .

\section{Profile of Promoting Company}

ABC Seeds and Biotech Ltd is a company primarily engaged into production and marketing of seeds in India. Established in 1982, it has carved a niche for itself in the seed industry and is positioned among the top ten private seed companies in India in terms of turn-over and cultivation area covered.

The spectrum of seed crops covered by the company includes crops like soybean, wheat, hybrid cotton, pulses and vegetables. Its forte has remained in field crops specifically soybean and wheat, wherein " $A B C$ " brand is not only well-accepted but also commands a premium. It had started the operations focusing on these two crops and this focus combined with the vast experience has resulted in ABC Seeds and Biotech Ltd is gaining a significant market share and an unshakeable hold in these crops.

$\mathrm{ABC}$ Seeds has a rich experience in production of field crops specially soybean and wheat. The seed production process at $\mathrm{ABC}$ is largely outsourced and decentralized so that the company can focus better on quality control \& field level inspections. The following are the key strengths of $\mathrm{ABC}$ in production area:

1. A production channel comprising of over 50 production organizers

2. A farmer base of over 5,000 who take the production program of company every year

3. Production network that spans through MP, CG, Maharshtra \& Gujarat

4. Quality assurance comprising of a team of 10-12 people to conduct field inspections of crops

\section{The Project}

The proposed project is for setting up the Infrastructure unit for Contract Farming under the Scheme for development/strengthening of agricultural marketing infrastructure, grading and standardization.

\section{Contract Farming Overview}

The proposed infrastructure is to be used for seed production through contract farming with farmers and production organizers. Under this, parent seed is distributed to farmers / production organizers, who grow it under contract with the company and under inspection of company officials and government quality certifying agencies. The seed crop, after harvesting, is supplied to the proposed godown, where it is tested for quality before acceptance.

Following are the salient features of the contract farming cycle:

1. Parent (Breeder/Foundation) seed is prepared by the company which is packed \& stored in the proposed godown. This seed is stored under proper ventilation \& insulation so that required moisture is maintained in the seed. 


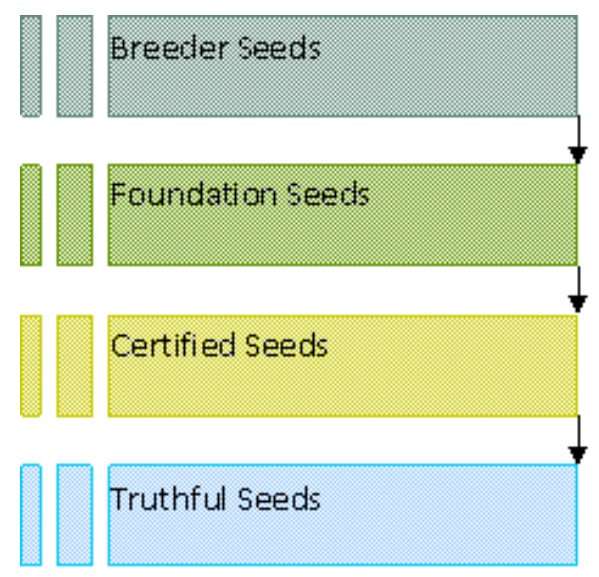

\section{Process Flowchart}

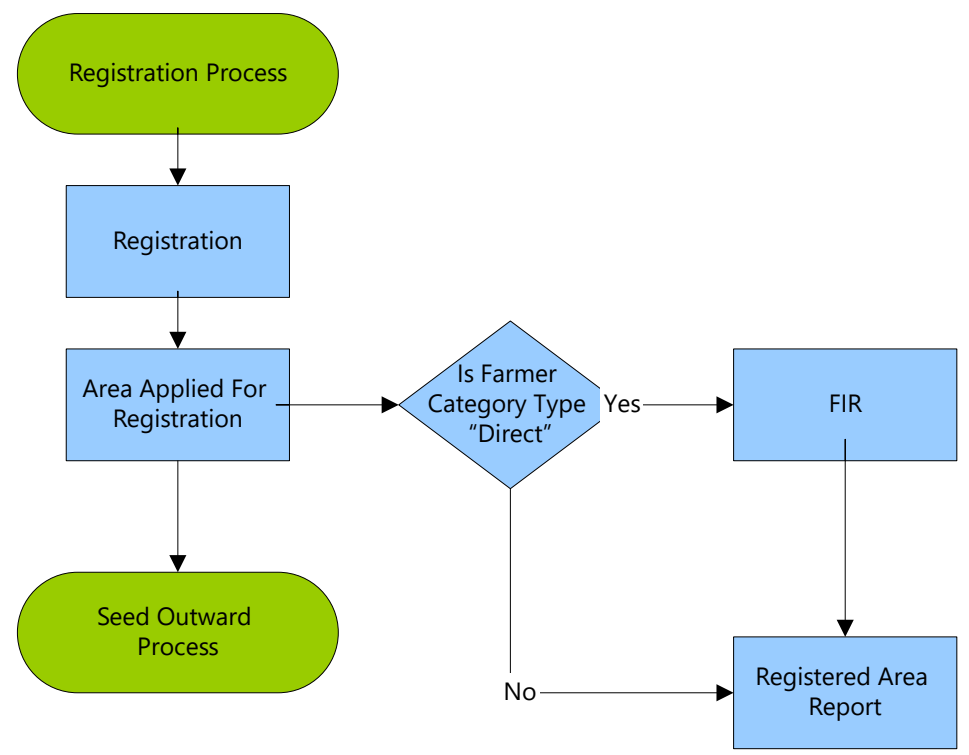

\section{Farmer Registration Flow Chart}

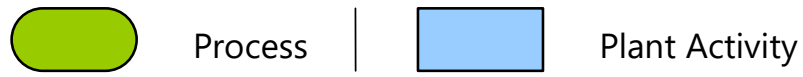

2. The parent seed is also stored in uniform stack sizes and entry of every seed lot stored in every stack is maintained in the computers provisioned in each godown. The details that are stored include:

a. Seed lot no., crop, variety information

b. Date \& month of packing

c. Details of farmer (Name, Address etc.) through which the parent seed has been procured

d. Quality parameters of parent seed (germination, genetic purity, moisture etc.)

e. Lineage of the seed i.e. details of its parental lot no.

3. This foundation seed is distributed under agreement to farmers through production organizers and a record of every seed lot distributed is maintained in computers. This distribution record includes:

a. Seed lot no., crop, variety information

b. Details of farmer to which it has been supplied

c. Area under which it has to be grown

4. The seed is then multiplied (grown) under a contract agreement with the farmer and is regularly inspected at his field by company officials \& certification agency.

5. When the produced seed arrives, it is tested for quality at the in-house QC lab for the following parameters:

a. Germination

b. Moisture \% 
c. Genetic purity / ODV

d. Undersize \%

If the seed meets quality standards of the company, it is procured at the said storage point.

\section{Flowchart}

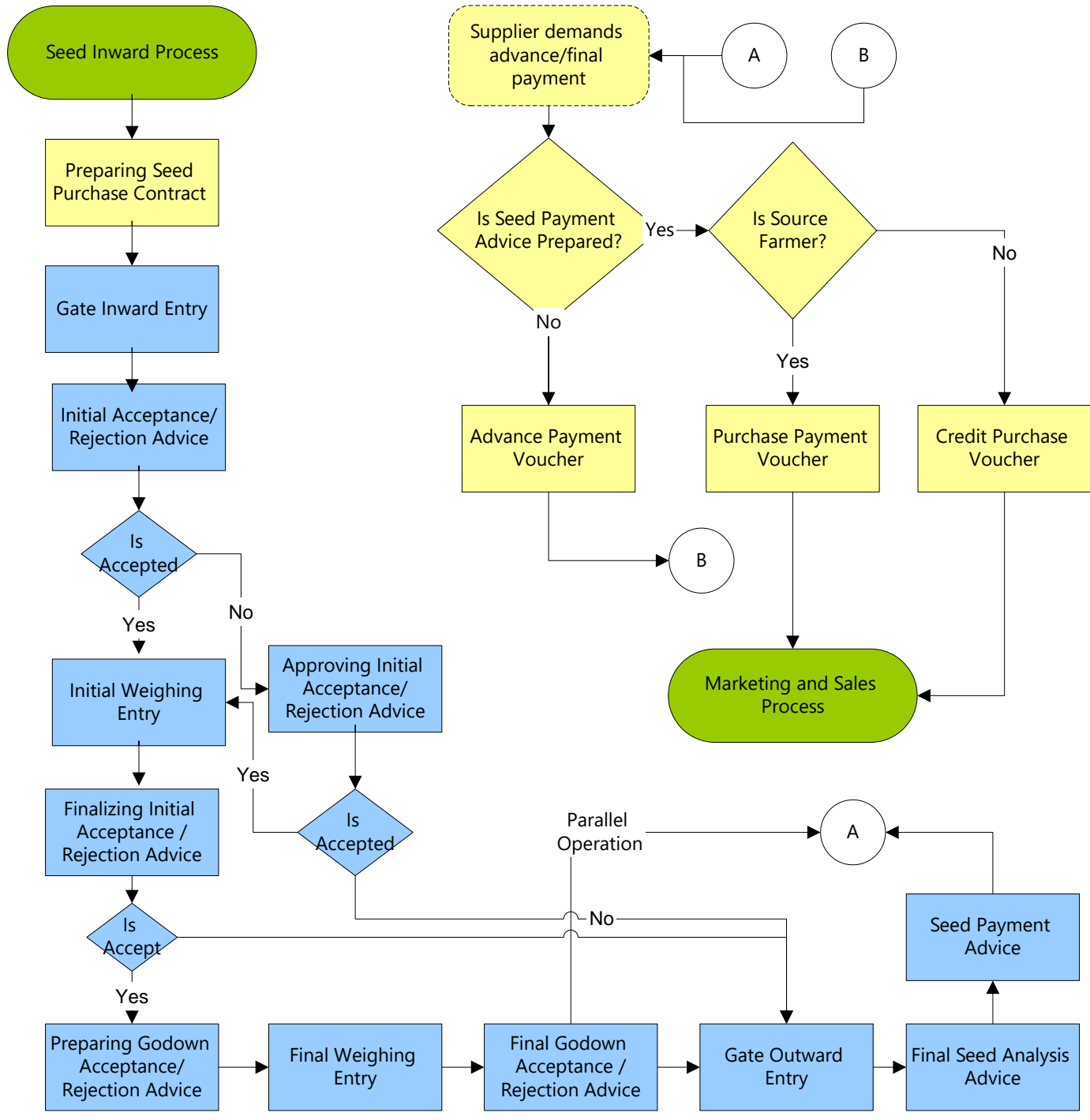

6. It is then sent for further processing \& packing.

\section{Facilities Proposed To Be Constructed For Contract Farming}

- $\quad$ Storage facility of about 40,000 sq ft with:

- Proper roof insulation to block temperature

- Suitable ventilation to maintain seed moisture

- Floor insulation to block ground moisture

- Stacking plan at floor with uniform stacks and passages for movement

- Computer, printer systems with cabins to maintain record of dispatches, arrivals \& stock details in the godown

- Quality testing instruments to test the arriving stocks

- $\quad$ Seed divider

- Seed Germinator

- Lab model grader

- Moisture meter

- Quality testing manuals

- Forklift or belt conveying system to transfer seeds for processing 
The Installed Capacity

The installed capacity of the storage for Cleaning and Grading unit shall be 6000 MT per year.

Central sector scheme on Grading, Standardization, Quality Control and Certification:

- Sale of agricultural commodities on the basis of standard quality grades mutually acceptable to the sellers and buyers and consumers would boost the marketing.

- A major deficiency in agricultural marketing is lack of grading, standardization and quality control. There is a need to focus on promotion of grading, sorting and standardization of farm produce to enable farmers to realize better price.

Compliance with international quality including hygiene and safety standards is becoming increasingly stringent and will have to be complied with if we have to be in the internal market.

- Standards have to be established for all agricultural products and be harmonized with international standards wherever required.

- There is also a need to adopt internationally recognized quality management systems and establish a credible system of registration of accredited laboratories for quality certification. Once the required grading, standardization and quality norms are fixed by appropriate agency of the Government, a major task would be to organize an awareness program amongst the farmers in the country in respect of such standards and for the purpose to organize a large number of training programs for the market functionaries.

- The Directorate of Marketing \& Inspection has formulated and notified standards for 163 agricultural and allied commodities under the Agricultural produce (Grading \& Marking) Act, 1937.

- The procedures for inspections, grading, labeling and quality certification are also notified along with these AGMARK standards.

- The domestic standards need to be harmonized with the international standards in a phased manner and popularized among farmers across the country.

- On the other hand, there is a persistent demand from consumer's welfare organizations through Ministry of Consumer Affairs and Public Distribution that adulteration prone food items should be covered under mandatory certification for reasons of ensuring safety of consumers. Since, this would be very difficult to manage such a programme, it is considered desirable to provide selective coverage of a few highly a adulteration prone items in packaged from in specified urban areas to start with under the existing programme.

- With a view to strengthen grading, standardization, quality control and certification, following areas will required to be taken up for development during Xth Plan.

\section{Market potential}

- The proposed plant is at Peer Karadia. The area around village of Indore District is having agricultural Produce as the main trading. The farmers and traders prefer to stock their agricultural materials here due to its close proximity of Indore Mandi.

- There is felt need of such facilities which promote farmers to market and enable them to hold the graded, cleaned and standardized materials to the bulk buyers of the agro commodities of the Metropolitan cities.

- Farmers prefer to hold goods in the warehouse for better deal in the price, so the profitability of the farmers shall grow.

- Indore is called the soyabean city and due to several big soyabean plants the farmers prefer to keep their soyabean in warehouses rather going for distress sell of the produce.

- Locational advantage of Indore and its good connectivity with other parts of India.

- The new system will improve quality comparable with international quantity thereby boosting export business.

\section{Land and Site Development Location}

The location of the infrastructure is at Village on A.B. Road, Indore and is well connected by all the major roads and about $0.5 \mathrm{KM}$ from the Ring road and $0.8 \mathrm{KM}$ from Indore Mandi, The location is ideal as the area has its identity for the godown and is well known by the farmers and traders of the agro produce.

\section{Land}

The firm had purchased the agriculture land at village in District Indore, measuring $3600 \mathrm{sq} \mathrm{mts}$. The said piece of land has been duly diverted by the competent authority for uses other than agriculture. The Company proposes to set up the Contract Farming unit in this piece of land. The layout and map is attached herewith.. 


\section{Site developments}

The project of infrastructures requires the roads for the movements of the Lorries and parking area. The entry to site is from the road connecting to A.B. Road, where Tar roads 30 Feet wide already exist. The cost of the site developments comprising internal and approach roads, fencing, and gate etc. are estimated at Rs 11 Lacs as per the estimates.

\section{Cost of building and civil works}

There will be two sheds in the project, out of which one shed shall be used for the storage of the materials and one shall be used for the processing and packing purposes and intermediate storage.

This is a marketing infrastructure project under the scheme of NABARD.

The cost of the building comprising the warehouse, office rooms, Kisan Sabha Griha , shed for the processing of the agriculture produce and packing section as given below. The detailed cost estimates are also furnished by the engineer of the firm.

\section{Preliminary Expenses}

The preliminary expenses are not expected to be incurred in the project

\section{Utilities}

Water:

The water to project shall be made available to the unit from the boring of proposed at site and adequate water is available

\section{Power:}

The Power is required only for the running of the machines, packing machine General lighting, etc and a $25 \mathrm{HP}$ Power connections are proposed in the scheme for take care of requirement of power in the warehouse. The entire warehouse operations are carried out in the daylight only.

- In-house 50-ton weigh bridge

- HT connection for uninterrupted processing operations

- Motorola ${ }^{\circledR}$ Canopy ${ }^{\mathrm{TM}}$ Wireless radio link between office \& plant for seamless connectivity

- $\quad$ R\&D \& evaluation facilities of 50 acres

\section{Cost of Project}

The cost of the project has been estimated at Rs.174 Lacs, comprising the site developments, building and Civil works of site improvement, etc as per the following estimate

\begin{tabular}{|c|c|c|c|c|c|}
\hline \multicolumn{6}{|c|}{ Project :- Infrastructure for Contract Farming } \\
\hline \multicolumn{6}{|c|}{ Under Scheme for development/ Strengthening of Agricultural } \\
\hline \multicolumn{6}{|c|}{ Marketing Infrastructure, Grading and Standarization } \\
\hline & & & & & \\
\hline & & & & & Amt. in Rs. \\
\hline S.no. & Item & Annexure & Cost & Bank & Promoter's \\
\hline & & & & Loan & Cont. \\
\hline & & & & $\begin{array}{l}\text { / Subsidy/ } \\
\text { Promoter Contribution }\end{array}$ & \\
\hline 1 & Civil Construction & A & $7,536,500$ & $3,768,250$ & $3,768,250$ \\
\hline & (Shed Godown) & & & & \\
\hline & Pre-Engineered & & $6,937,500$ & $3,468,750$ & $3,468,750$ \\
\hline & Structure & & & & \\
\hline & ( Roofing \& Cladding) & & & & \\
\hline & & & & & \\
\hline 2 & Roads & $\mathrm{B}$ & $1,100,000$ & 550,000 & 550,000 \\
\hline 3 & Funiture and Fixtures & $\mathrm{C}$ & 150,000 & 112,500 & 37,500 \\
\hline 4 & Computers & $\mathrm{D}$ & 72,500 & 54,375 & 18,125 \\
\hline & & & & & \\
\hline 5 & $\begin{array}{l}\text { Land in the project cost - } \\
10 \% \text { of PC }\end{array}$ & & 224,020 & 0 & 224,020 \\
\hline & Total Cost & & $16,020,520$ & $7,953,875$ & $8,066,645$ \\
\hline & & & & & \\
\hline & $\begin{array}{l}\text { Subsidy - From NABARD / } \\
\text { DMI }\end{array}$ & & $\begin{array}{r}\text { 40,00,000/- Say } \\
\text { Rs. 40 Lacs }\end{array}$ & & \\
\hline
\end{tabular}

Note: Escalation if any in the cost of the project shall be met by the promoters and therefore no contingencies are provided in the scheme. 
Means of Finance

The means of finance proposed by the Concern is as per the Project Cost Statement is :

Means of Finance

$\begin{array}{lccc}\text { Capital } & : & \text { Rs } & 40 \text { lacs } \\ \text { Term Loan } & : & \text { Rs. } & 120 \text { lacs } \\ \text { Capital subsidy: } & & \text { Rs. } & (40) * * \text { lacs }\end{array}$

The bank shall finance the fixed assets cost with $25 \%$ margin.

On the basis of above finance mix, the debt equity ratio for the proposed project comes upto 3.2 excluding subsidy amount of Rs 40 lacs..

\section{Security and Finance}

The bank shall have exclusive charge on all the land and development site of the concern in their favor, in addition to personal guarantee of the proprietor of the concern. The present market cost of the land is about Rs 10.00 lacs

\section{Back Ended Capital Subsidy}

The concern will be eligible for the capital subsidy of Rs 40 lacs which will be back ended in nature and shall be adjusted with the fixed assets of the company at the end of the 2 years of the Term Loan. Will the term loans at the end of the period when the outstanding term loans portions remains Rs 40 lacs.

Term loan is secured by way of first charge on the assets of the concern. The organization shall receive the Back ended Capital Investment subsidy of Rs 40 lacs, as per the scheme and shall be adjusted in the loan account at the end of the period when outstanding loan and interest remains Rs 40 lacs at the end of the loans. However no interest shall be charged on this portion of the subsidy and shall be kept in the subsidy reserves account.

\section{Conclusion}

Businessmen are taking more benefit of this scheme.

- Post construction what's the monitoring mechanism, to ensure that funds of subsidy are used to the end cause for which they have been deployed.

- Benefits to the farmers against the deployed funds by the Bankers and Subsidy

- Generally it is found that post subsidy adjustment, facilities are used for other purpose and not only on which GOI has funded for.

- We also feel that a Annual Performance Report on each project has to be made and a district wise analysis of funds end use monitoring management system is to be taken care of.

- Though the scheme has been promoted in Tribal Area but there is not specific guidelines as to what shall be the implication if a female farmer has to prepare

- Food disparity has increased. Farm produce of one mandi cannot be sold in another Mandi.

- Inflation is basically a food inflation. 